\title{
Social Priorities and The Market Allocation of Credit ${ }^{*}$
}

\author{
Speech by DARRYL R. FRANCIS, President, Federal Reserve Bank \\ of St. Louis, to the College of Business and Industry, \\ Mississippi State University, February 23, 1971
}

I.

$N$ RECENT YEARS there has been much discussion conceming financial responsibility for the allocation of resources for social goals. Some contend that there is a widening gap between the performance of our financial institutions and the desires of society. They assert that society is concerned primarily with the relative shares of total expenditure in individual sectors of the economy, and that this is inconsistent with the concem of national monetary policymakers for aggregate activity and the profit motive governing the private financial community.

For several decades many economic sectors have allegedly fared unfavorably from the market allocation of resources, especially the allocation of credit. Such sectors include housing, state and local governments, small business, low income groups, and agriculture. A natural consequence of this alleged inefficient allocation of credit has been a number of proposals designed to improve the system of credit allocation.

In a world of scarce resources the allocation of credit is an important function. It is a major determinant of the type and quantity of goods and services available to consumers. This function can be performed either through competitive markets or on the basis of social priorities administered by the govem ment. Allocations through the marketplace are the result of individual decision-making in the daily purchasing of goods and services. Such purchases indi-

\footnotetext{
*The issues discussed in this speech have been presented to other groups recently by President Darryl R. Francis.
}

cate to producers the type and quantity of goods and services desired by consumers. Producers in turn purchase resources such as labor and capital to provide a level of production necessary to meet consumer demands at market prices. In contrast, social priorities are actually restrictions imposed on the community by delegated authority. In making the choice between these systems of resource allocation, we are faced with issues concerning both economic welfare and freedom.

In this discussion I shall contend that the maintenance of maximum welfare in individual sectors is consistent with both a monetary policy concerned primarily with aggregates and the profit motive of private financial firms. Most shortcomings in financial market performance in recent years were the result of impediments to the operation of free markets. Credit controls designed to alleviate alleged hardships often do not alter resource flows in the socially desired direction. If aid to low income groups is the social objective, cash payments are a more efficient means of providing assistance than credit reallocations.

I believe that the market system of credit allocation is superior to any other system. It provides greater economic welfare and more individual freedom of choice. Rather than attempting to improve welfare in specific sectors, the monetary authorities can make a greater contribution to overall welfare by concentrating on the maintenance of national economic stability. Given the appropriate actions for overall stability, market forces will assure that individual sectors are treated equitably in a competitive 
enterprise economy free from excessive restrictions. Consumer preferences as reflected by demands for goods and services will provide the incentive for producers in each sector to acquire necessary resources, including credit, for a level of output consistent with maximum satisfaction.

\section{Case for Social Priorites Overstated}

Most of the impetus for setting social priorities on credit flows or on goods and services produced has occurred during periods of great depressions or of high nominal interest rates (notably agriculture in the 1930 's and housing more recently). When market rates exceed limits established by usury laws, Regulation $Q$ and other restrictions on savings yields, credit flows are diverted from normal patterns. These market barriers have tended to starve some sectors, while other sectors not subject to the regulations have paid the market rates and obtained more funds than would have been available under free market conditions. Such restrictions, however, probably have little effect on the total volume of credit or savings.

In order to correct the assumed defects of capital and credit markets, proposals have been made to es. tablish priorities on credit flows through various financial agencies, including the Federal Reserve System. ${ }^{1}$ Variable reserve requirements against bank assets, selective open market purchases, the discount mechanism, moral suasion, quotas, margin requirements, and direct controls have been suggested as means for altering credit flows to specific sectors. If reserves were required against assets rather than liabilities, and it was desired, for example, to increase investment in housing relative to other investments, required reserves could be increased on other investments and reduced on residential mortgages. This would provide incentive for banks to make more residential mortgage loans. It has also been suggested that Federal Reserve Open Market purchases include FNMA securities, thereby increasing the volume of funds available for home mortgages.

\section{Credis Prorities Included in}

\section{Federal Reserve Aot}

A number of credit priorities were included in the discount provisions of the original Federal Reserve

\footnotetext{
1See Tom Connors, "Variable Reserve Requirement Imposition Opposed by Burns," New York Journal of Commerce, April 1, 1971, and "Bunting Opposes Fed on Credit Allocation," American Banker, April 19, 1971, for discussions of this subject.
}

Act. Agricultural paper, for example, was given the special consideration that maturities of such paper not exceeding six months (later extended to nine months) were eligible for discount. Short-term paper, or real bills, arising from commercial transactions was likewise given preference over most other instruments in the credit market. Maturity requirements were more stringent for other paper.

With the decline of the discount mechanism as a major monetary policy instrument in the 1930 's, this means of channeling credit to areas with high priorities declined. Other restrictions on credit, however, tended to offset this move toward free market allocation. Margin requirements placed on stock market credit may have channeled a small amount of funds to other areas. At the beginning of World War II, the buildup of defense industries was given high priority and received aid through the $\mathrm{V}$ loan program administered by the Federal Reserve. Consumer credit controls were instituted about this time, and both consumer and real estate credit controls were used during the Korean conflict to reduce credit and demand for resources in these sectors. ${ }^{2}$ Following World War II and the Korean buildup, the central bank reverted to its pre-war position with respect to credit allocation.

As market interest rates increased in recent years, Regulation $Q$ and other restrictions reduced credit flows through normal bank channels. These restrictions probably resulted in a loss of funds to the housing industry and a gain to other sectors which could pay market rates for the diverted funds.

Since credit flows are an important determinant of production, the problem of credit allocation is similar to that of allocating other resources. The solution depends upon whether the individual should be given freedom of choice in the marketplace to decide what goods and services will be avallable for consumption, or whether this decision should be imposed on the individual through social action. It is my belief that such rights to choose goods and services for consumpm tion should be left to the individual.

\section{Public Action Appropriate for}

\section{Some Activities}

I recognize that a number of functions can be performed more efficiently in the public sector. Maintenance of social order, air pollution control, common

2Federal Reserve Bulletin, September 1941, p. 825-836; October 1950, p. 1314-1321; and December 1950, p. 1577-1581. 
defense, and monetary controls provide general benefits which cannot be completely captured by an individual. For example, air pollution control, which may require considerable expenditure by some sectors, provides substantial benefits to the entire community. Some producers and consumers in minimizing costs fail to control harmful waste products. Such polluting activities which violate the rights of others to clean air and water must be regulated by government action.

A lighthouse is a classic example of a service that should be in the public sector. It provides equal benefits to both owners and nonowners of ships in its vicinity, and its use by one ship does not reduce its services for other vessels. We justify expenses for public education on the basis that all citizens receive some benefits from the educated individuals. In order for the public to gain the benefits of such public goods and services, collective expenditures are necessary. These expenditures may not provide benefits to taxpayers in proportion to the taxes collected from each individual, but the alternative may result in the elimination of services with a consequent reduction in welfare to the entire community.

\section{Private Action More Efficient for Most Activities}

In contrast to activities which are performed more efficiently in the public sector, most economic benefits readily accrue to the individual without specific community action. Given the premise that individuals spend their funds so as to maximize satisfaction, individual expenditures for goods and services provide a more efficient guide to producers than do priorities established by legislative action. The establishment of legal priorities is simply a method of substituting collective for individual decision-making.

The establishment of priorities involves a tradeoff of one type of activity or good for another. Total volume of goods and services produced is not increased. The diversion of resources to enhance output in one sector, such as residential housing, with a reduction of resources in other areas, however, is not neutral with respect to economic welfare. If marginal expenditures by each person result in optimum satisfaction prior to the diversion, the goods and services foregone are of greater value to consumers than the gains from the additional houses. In other words, given the pattern of income distribution, the additional houses provide less welfare than would have been provided by the goods and services foregone, as indi- cated by free market purchases prior to the arbitrary diversion. Thus, such socially established priorities force individuals into a pattern of expenditures which provides less-than-optimum want satisfaction.

There is also a possible tradeoff between housing and other forms of wealth, with no resultant decline in current consumption. For example, given full use of resources, more houses could be built at the expense of investment elsewhere without reducing other types of current consumption. The long-run impact of such action would reduce national wealth and goods and services available for consumption in future periods.

One prime example of the inefficiency of producing under arbitrarily determined priorities in the United States is our agricultural programs of the past several decades. In the 1930 's and again in the 1950 s, farm incomes were thought to be too low relative to incomes in nonfarm occupations. We first moved to remedy the alleged problem by setting a floor under farm commodity prices with the aid of a government price support program. Price supports were generally established above free market levels, thus providing incentive for production of a surplus of farm products. Our stocks of farm products, which were purchased by the government in its price support operations, soon rose to enormous levels. Numerous measures have been taken to reduce these stocks, including subsidized exports, subsidized school lunches, food stamps to low income groups, a land rental program to remove millions of acres of cropland from production, and crop allotments which arbitrarily limit the acreage planted to many crops. The alleged problem and inefficient programs continue.

Fundamental economics tells us that the long-run market price is the only price providing just enough incentive for farmers to produce the quantity of farm products that will clear the market. It is the only price which will avoid an accumulation of excesses or shortages. The market price is also the only price that will provide sufficient incentive for labor and other resources to adjust between agriculture and other sectors of the economy so as to maximize overall economic output. Other resource combinations will tend to reduce output and thus the volume of goods and services available to consumers.

Agriculture, like other sectors of a competitive economy, is self-adjusting, provided that market forces are permitted to operate freely. If incomes to farm resources are too low relative to returns in other areas, more farmers and farm youth will obtain em- 
ployment in the nonfarm sector. Similarly, if incomes rise higher in agriculture relative to other sectors, we will have an expansion of farm workers until returns to workers of equal ability are equal in all sectors of the economy after allowance for nonmoney factors.

Our public housing is another example of the wasteful use of resources based on public ordering of production. Despite the sizable subsidies provided occupants, a large proportion of public housing units are often vacant, and the operations are in a constant state of insolvency.

Such waste of resources resulting from public decisions is not limited to our nation or our time. Modem hotels built by govemments of some underdeveloped countries where few potential customers reside are now largely vacant. The numerous edifices of the Middle Ages and the very expensive royal mausoleums of ancient times are examples of resource diversions which were detrimental to most of the people.

Social priorities which increase flows of some types of goods and services, in addition to their inefficiencies, are extremely biased against those individuals who already possess adequate amounts of these goods and in favor of those who are in the process of purchasing such goods. For example, those persons who already have adequate homes are penalized when resources are diverted from other areas through social action to home building. With fewer resources allocated to other areas, all consumers must pay a higher price for nonhousing goods and services. In contrast, only the prospective home purchaser gains from the subsidy on home construction or home financing.

It is true that the private sector makes errors in resource use. Here, however, the decision-maker suffers a financial loss when resources are used inefficiently, giving him great incentive to avoid waste. Obviously, all individuals and firms do not have equal access to credit markets, as access is determined in part by the assets of the borrower. Nevertheless, lending is determined in part by the anticipated productivity of capital. Furthermore, the market system minimizes waste of scarce credit resources and thereby provides more funds to all productive uses. In contrast, other methods of allocation offer no assurance that efficient use of credit will be achieved.

\section{Cash Payments Most Efficien for Welfne}

The allocation of goods and services through social priorities is an inefficient means of providing welfare to lower income groups. The well-being of the lower income groups would be enhanced more by money income than by the same amount of income diverted to them in the form of housing subsidies. The subsidy forces a pattern of consumption on these groups which conforms to the authorities' tastes, not the individual's. The value of this forced spending pattern to the individual is not as high as the value of an equal amount of funds. It is, therefore, my conclusion that efforts to improve the welfare of lower income groups should be limited to direct transfers of funds rather than providing particular goods and services. The supposedly wasteful consumption patterns on the part of some households are not a sufficient reason for a government or central bank to alter these patterns. Our own spending patterns may appear similarly unwise to others; any government edict altering our consumption patterns detracts from our personal wellbeing.

\section{Controlling Financial Flous Difficul}

In addition to the inefficiencies created by arbitrary credit allocation, attempts to ater financial flows in the past have been less than satisfactory. The recent period, in which Federal Reserve Regulation $Q$ and other interest rate restrictions limited the yield on savings accounts, shows the complex nature of credit allocation. ${ }^{3}$ While an objective of the restrictions was to maintain low interest rates to home purchasers, the reverse was closer to the actual result. Supply and demand forces in financial markets were not given sufficient consideration. The flow of savings through financial intermediaries was retarded, as many savers invested their savings at higher rates in other assets not subject to the restrictions. This tended to reduce the supply of funds to savings institutions - the major suppliers of home mortgage credit. Mortgage loan demand, however, rose as a result of rising total demand caused by excessive money creation, and the rates charged on new mortgages rose sharply. The restrictions actually diverted funds away from home mortgages and caused higher rates to home purchasers than would have been charged had banks and savings and loan associations been free to compete for deposits through interest rate adjustments.

The proposed variable reserve requirements on bank assets may likewise yield unexpected results. As in the case of Regulation $Q$, if these restrictions lead to inefficiencies in banking, savings will bypass the

"Charlotte E. Ruebling, "The Administration of Regulation Q," this Review (February 1970), pp. 29-40. 
commercial banking system. The nation's larger business firms have direct access to money markets if banking efficiency in meeting their demands is impaired. Other credit agencies can offset bank credit diverted from low priority consumer uses.

Commercial banks are only one of several agencies which channel funds from savers to investors. Estimates published by Bankers Trust Company, New York, indicate that commercial banks supplied less than 20 per cent of all investment funds raised in 1969 and only about 25 per cent of all short-term funds raised. ${ }^{*}$ of the total investment funds supplied, both the contractual-type and the deposit-type sav ings institutions exceeded the quantity raised by commercial banks. The contractual institutions, which in clude life insurance companies and private and government pension funds, raised an estimated $\$ 23$ billion - more than double the amount of such funds raised by commercial banks.

Commercial banks likewise supplied a relatively small portion of the short-term funds raised - only $\$ 9.5$ billion of the $\$ 38.6$ billion total. All other savings institutions supplied $\$ 6.4$ billion. Almost two-thirds of the total raised, $\$ 24.4$ billion, was supplied by other business corporations. Other investor groups such as brokers, consumer lenders, and foreign investors were net users of $\$ 1.7$ billion of short-term funds. These nonbank sources of investment funds may completely offset efforts by the monetary authorities to enhance credit flows to specific sectors.

\section{Federal Reserve Should Concentrate On Economic Stabilitaton}

Finally, and probably more important, is the fact that attempts by the central bank to stimulate or retard activity in specific sectors may not be consistent with the maintenance of appropriate monetary policies for economic stabilization. The Federal Reserve System is eminently qualified to stabilize overall economic activity, provided it is not hampered by excessive duties and restrictions which have little in common with this overall objective. Once the System becomes excessively concemed with activity in individ ual sectors rather than with the economy as a whole, its usefulness will be greatly inpaired, ${ }^{5}$

Bankers Trust Company, The Investment Outlook for 1971, New York, 1971 , pp. $10 \mathrm{~m} 11$.

5 For further discussion of this point, see a statement by Arthur F. Burns, Chairman, Board of Governors of the Federal Reserve System, before the Subcommittee on Financial Institutions of the Committee on Banking, Housing and Urban Affairs, United States Senate, March 31, 1971.
It is doubtful that the Federal Reserve can detect the forces contributing to change in economic activity in specific areas better than other market participants. Some lines of activity decline because of changes in basic supply or demand factors not associated with financial impediments. Such factors are automatically detected and acted upon in the marketplace, where the appropriate resources are adjusted to meet the changed conditions. Waste of resources is minimized during the adjustment process. It has been my experience that the application of specific govermment programs to ease the burden of such adjustments has not only been inefficient but has also prolonged the adjustment period unnecessarily. Our programs for agriculture are examples of such inefficiency. The Federal Reserve is not likely to improve on this poor record of other government agencies by attempting to alter economic activity in specific sectors through credit allocation.

The loss by some sectors of rights to equal access to credit markets, like other restrictions on economic activity, is a further unnecessary encroachment on individual freedom. As indicated earlier, any social action which channels funds to one sector of economic activity reduces the volume of funds available for other sectors. This loss of funds to sectors having lower priority is an impingement on individual rights to purchase savings at market prices.

\section{Conclusion}

In conclusion, the case for establishing high social priorities for output in specific sectors of our competitive private economy has been greatly overstated. The use of legislative action to increase output in specific sectors is a means of determining through collective rather than individual decision-making what goods and services will be produced. We can justify some collective decision-making during national emergencies on the basis that it is necessary for survival, but the competitive market is a more efficient allocator of resources most of the time.

Many suggestions for setting priorities on credit flows have occurred during periods of high interest rates or major depressions resulting from ill-advised public policies. The maintenance of a fairly stable rate of growth in the stock of money and removal of useless regulations will permit the free-market system to work effectively and alleviate most of the observed problems.

This country's record of performance in establishing social priorities in the private sector has been less than 
successful. Our farm programs designed to correct the alleged illness of income allocation are examples of such failures. Earlier price support programs which ignored basic supply and demand forces were followed by more expanded programs to correct newly observed problems. Like the proverbial punching bag that expanded elsewhere when punched from the front, each new regulation created another problem that required new legislation. We still have not been able to get the government out of agriculture, and the expanded programs continue at great social cost. Such regulations have been a factor in retarding our farm export markets. They have reduced output in both the farm and nonfarm sectors of the economy and have been relatively ineffective in increasing returns to individuals. Their proponents fail to recognize that resources, including labor, adjust to income incentives in all sectors.

To the extent that the authorities are successful in altering credit flows and production pattems in the private sector, they reduce national welfare. Production based on collective decisions imposes a spending pattern on the individual that is not compatible with maximum want satisfaction. If an increase in the welfare of the low income groups is the objective of such actions, welfare can be purchased at a lower cost through cash grants than through credit subsidies for specific goods and services. With cash grants, each person can obtain maximum want satisfaction for each dollar spent. In contrast, subsidies of goods and services impose the spending pattern of a group on the individual.

Finally, the Federal Reserve is not an appropriate agency to be in charge of social priorities. The use of such mechanisms as variable reserve rates on different bank assets to alter credit flows increases the problem of maintaining control over monetary aggregates. Control over these aggregates is essential for economic stabilization. More important is the fact that attempts to maintain economic health in specific sectors of the economy will detract from the central bank's overriding responsibility for appropriate stabilization policies for the total economy.

If a stable rate of growth is achieved in total economic activity, the freely functioning credit and capital markets will provide the most efficient allocation of funds to specific sectors. It is through this route of providing sufficient flows for an appropriate level of total activity that the central bank can make its maximum contribution to national welfare. 